\section{Battle of the research councils shows no sign of abating}

London

BICKERING over the control of UK government-backed biotechnology broke out in public last week, leaving no doubt that effective collaboration between the Medical Research Council (MRC) and Science and Engineering Research Council (SERC) is as remote as ever, and that MRC and the Department of Trade and Industry (DTI) are also at loggerheads over biotechnology.

DTI's chief engineer and scientist, Ronald Coleman, began a two-day discussion meeting at the Royal Society by saying that positions were hardening and rivalry intensifying between the research councils. In a barely veiled attack on MRC, he criticized the inflexibility of permanently staffed research institutes devoted to curiosity-led research. In response, MRC secretary Dai Rees reminded his attacker that it was on innovatory research in $\mathrm{MRC}$ institutes that much of biotechnology was built, and that overmanagement stifles innovation.

Many speakers measured achievements in biotechnology against the hopes of the 'Spinks Report' of 1980 , which recommended the measures needed to boost British industrial development in biotechnology. The report recognized that all the research councils had a legitimate interest in biotechnology and called urgently for a coordinated programme of research, and a greatly increased budget.
Reviewing subsequent events, Margaret Sharp of the University of Sussex's Science Policy Research Unit reminded the audience that the government of the day flatly refused to finance a gap that it felt industry should fill, and that MRC in particular blocked an effective coordination between research councils. In large part, she said, this was because Rees's predecessor, Sir James Gowans, was unwilling to push MRC in the direction of strategic research that SERC had adopted with the founding of their Biotechnology Directorate in 1981. Instead he strongly backed the foundation of Celltech, now Britain's leading biotechnology company, to exploit ideas emerging from MRC research.

"There are still problems of difference in ethos; ours works and delivers to industry", said Rees, who recently founded the Collaborative Research Centre (see below) as another way to exploit MRC discoveries. While Margaret Sharp argued for belated cooperation, saying it was particularly absurd that the protein engineering programmes of all the research councils and the DTI were not carried out as a national programme, Tom Blundell of Birkbeck College defended pluralism. "We would lose", he said, from an overseeing directorate that dictated one mode of research, adding that there was no lack of collaboration among the researchers themselves.

\title{
Mill Hill centre promotes innovation
}

\section{London}

THE Medical Research Council (MRC) Collaborative Centre, formally opened this week, is the council's latest way of helping to plug the notorious UK predevelopment gap. Companies interested in an MRC invention will pay for a 1-3year project at the centre to explore the invention's commercial value.

At present, about a dozen projects are in operation, but there is room for several more. Nearly all the current ideas have been generated at the MRC National Institute for Medical Research, which is on the same site in Mill Hill, on the northern outskirts of London. Most of the industry involved so far is British but a few US companies already sponsor projects.

Work in progress at the centre ranges from biosensors to protein purification, although a focus on antiviral agents and antibodies has emerged in the two-year run up to the official opening of the centre.

Typically, the project is carried out by staff specifically employed on short-term contracts, with the inventor acting more or less as a consultant. There are no consultancy fees but an attempt is under way to circumvent the rules that prevent payment, says the centre's business manager, William Matthews.

For the company, which pays the full costs of the project including overheads, the perceived attractions of the centre include regular progress reports and a guarantee of full confidentiality, which is often not forthcoming from academic collaborators.

This year, MRC will still provide some 40 per cent of the costs of the centre, but it is on course for being self-financing by 1991. The centre will not generate profits. Instead, MRC should ultimately benefit by increased licence and royalty fees.

Making the most of the fact that Kenneth Baker, Secretary of State for Education and Science, was present to perform the opening ceremony, MRC's chairman Lord Jellicoe said that the centre looked forward to the day when it is receiving more alpha-rated projects than it can handle - a position already unfortunately reached by MRC itself. Peter Newmark
At the discussion meeting Sharp said that, contrary to some expectations, the strong industrial presence on the directorate's management committee "far from pushing towards the applied end (of biotechnology research) has done more or less the opposite". And with DTI now in general switching its support from 'nearmarket' to 'pre-competitive' research and development, firmer links than ever are being forged between the Biotechnology Directorate and DTI's Biotechnology Unit.

MRC may see this shift as a point in favour of its gaining control over SERC's biotechnology funds, which it has been eyeing for some time. But Sharp argued strongly for building on what was already in existence rather than switching horses in mid-course.

Peter Newmark

\section{Endangered species}

\section{Washington}

President Ronald Reagan has signed a bill to strengthen the 15-year-old Endangered Species Act. Besides toughening penalties for breaking the law, the bill lays out for the first time a scheme to protect the African elephant population, reported to have declined by nearly 50 per cent since 1979 .

The bill gives the Department of Commerce $\$ 1.5$ million until the end of 1989 to

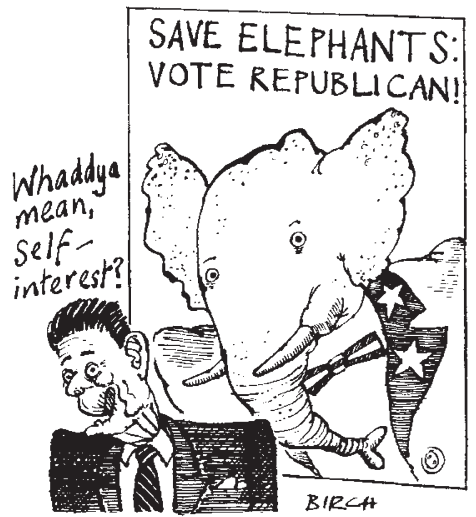

spot species at risk and develop a recovery plan for them. The Secretary of Agriculture will provide financial assistance to any state cooperating in the plan. And there is special emphasis on a follow-up programme to monitor for at least five years those species which have recently been recovered and removed from the endangered list. The bill raises the lowest penalty for violating the provisions of the act from $\$ 10,000$ to $\$ 25,000$, and the highest from $\$ 20,000$ to $\$ 50,000$.

A separate section of the bill sets up limits on imports of raw and worked ivory into the United States, to prevent the poaching of African elephants (see Nature $333,290 ; 1988)$. In order to trade with the United States, ivory-producing countries must follow strict rules set up by the ivory control system of the Convention on the International Trade in Endangered Species. Elizabeth Berendt 